\title{
Identity in Contemporary ASEAN
}

\author{
Nuraeni \\ Department of International Relations \\ Universitas Padjadjaran \\ Bandung, Indonesia \\ Syarif Hidayatullah State Islamic Uniersity Jakarta, Indonesia \\ nuraeni@unpad.ac.id
}

\begin{abstract}
Regionalism always engages long discursive processes to compromise some gaps or disparities among member countries. This paper will explore how contemporary Southeast Asia countries are dealing with the problem of identity as inevitable, especially in very large plural society like this region. Constructivist view will be used as a conceptual framework, particularly the notion about political initiatives or policies have to come along with a commitment to always appreciate every aspect of lives including the identity. Furthermore, every regional cooperation must contribute to the growing need for collective cohesiveness between nations and regions without nullify or marginalize some individuals and groups regarding their identities.
\end{abstract} ASEAN

Keywords-Politics; Identity; Regionalism; Constructivist;

\section{INTRODUCTION}

Regional cooperation has evolved along with the dynamics of international actors, both state and non-state. Movements, interactions and transactions of non-state actors are increasing rapidly in the issue of economic, political, social, cultural, health, environmental and so on [1]. Under such circumstances, the need for cooperation within the region has not been driven by the national interest alone [2]. ASEAN as one of the most important regional organizations in the international political arena cannot ignore the importance of understanding the dynamics. The greatest challenge for ASEAN is no longer the level of perception of political elites to their respective national interests, but the level of socio-cultural, both domestic and regional. However, the dominance of political and economic issues has risen the marginalization on other issues. From the beginning, ASEAN established through Cold War grand narratives such as "political stability", "economic stability" and "security stability." This paper will discuss the identity issue which had been underrated in regional level.

\section{METHOD}

Southeast Asia is currently showing a very interesting development trend since the region's survival from the Economic Crisis, which shook America and Europe. In this context, the constructivist view will be used to describe the relational complexity between the state as an actor and the state as a social contract, or in other words the embodiment of the commitments of individual actors and social groups [3].
Identity issue in in the regional cooperation is not merely the final result of the achievement of mutually beneficial cooperation, but is an important prerequisite in making it happen [4]. The success of the European Union became (EU) - as one of the most credible actors after the Cold War-cannot be, in fact, parted from the long history of the struggle for identity [5]. England's reluctance to enter the Euro zone could be a sign that the struggle has not really finished yet. The same struggle becomes a challenge that if realized and successfully passed, it is not impossible to strengthen the position of ASEAN, both internally and externally.

\section{RESULT AND DISCUSSION}

The Southeast Asian community should be understood in two ways at the same time: the community of countries and the community of people. Alexander Wendt, on the one hand, agrees with realists that the state is an agent that can act as individual; but on the other hand, he rejects the idea that states can form a common identity [3]. For Wendt, the possibility of the state forming a common identity is still open as long as the state is understood as both political entity and sociological phenomenon. The state was born and gets its identity from individuals and groups who are willing to sacrifice some of their self-interest to formulate a common goal. In this context, identity is defined as a shared value that is discovered and formulated together. Before the nation-state was discovered it was actually found in such forms as polis, tribes, religions, etc. The nation-state is apparently expected to be more accommodative to the differences that exist in society. The nation-state is obliged to protect its citizens without having to sacrifice other shared values, beyond any distinction. Thus, the nation-state is also possible to form a community between nation-states and establish an identity without having to destroy the values that already existed.

Wendt (1999) identified four types of identities. First, a personal or corporate identity which refers to a feature that expresses a particular unity that distinguishes it from others. As an example, the term "I" refers to the unity of the individual human both body and soul, while the nation-state refers to the unity of territory, population, sovereignty. Second, a typical identity which requires a first identity to express and/or attach it. This identity is related to the characteristics shown in the environment, such as educational background, language skills, group affiliation and cultural background. Each actor may have 
multiple identities simultaneously. Third, an identity that refers to the role of the actor in his environment or the position the actor hopes for himself, for example one's leadership or foreign policy - in the context of the state. Wendt is very conscious that he takes into account that there are other relationships in the relational aspect in each identity. He strongly agrees with postmodernists that the frequency of this aspect being ignored by rationalists. It is as though the individual or the state can formulate and calculate all its actions at once to formulate and account for what the other party will do in the same situation, without taking into account the different influences, which depends on the parties involved. In some cases, this view can be very dangerous. A case in point is when the United States imposed a massive military offensive into Iraq and Afghanistan following the 9/11 tragedy. Both the 9/11 and the American attacks show the strong view that others, whether other people or other countries, are threats - they would be either enemies or followers. If retained, these conflicts will continue to take its toll, in which, according to Wendt, would inhibit the formation of the fourth identity.

Those three identities are still more from the point of view of the first subject. Wendt believes that the nation-state is a rational actor who moves beyond the instigation of their own interests. Nevertheless, the rationality of actor cannot necessarily give nation-state the right to ignore the interests of others. Hence, the fourth identity is the logical solution of the relationship of the actor to the other, or the collective identity. This is really the battlefield in individual social life as well as the constellation of relations between countries. To achieve what is called as collective identity requires effort and a willingness to understand what others need is the same as what I need. Collective identity can only be born from openness to each other to appreciate each other's uniqueness. It will not always succeed in the first stage, but eventually it will, like the centuries-old European war that leads to the formation of European Union. Collective identity does not intervene the other three identities; it can even strengthen them. It should be noted that collective identity is a very dynamic identity area. Collective identity is generally experienced along with human experience themselves. A person's or group's understanding of its collective identity is greatly influenced by the understanding of space and time. As an example, the Youth Pledge has marked a new understanding of several groups of young people from various ethnic backgrounds in the archipelago over the concept of Indonesian-ness in the pre-independence era. Thus, collective identity is very likely to experience evolution and even revolution. Is it possible to formulate an Asian-Southeast Asian concept?

ASEAN is one of the regional organizations whose members are from various plural aspects-compared to the EU, African Union, Arab League, and several other large regional organizations. Demographically, countries in Southeast Asia each consist of different ethnic groups, religions, and use more than one language. This region was historically divided into colonies of Dutch East Indies, English, and Portuguese. The term "bangsa serumpun"are not really able to represent the plurality of this region. Another interesting fact shows that this region hardly experienced interstate wars in a prolonged region like Europe in the past, or Africa. Majapahit in the time of Gajah Mada was the only massive conquest of the region. However, it does not mean that the area is more neutral than other regions. Negative sentiments generally appear in bilateral contexts, such as
Indonesia-Malaysia, Indonesia-Singapore, Singapore- Malaysia, Vietnam-Cambodia and others. The historical relation and identity of the people of Southeast Asia have been widely studied; one of them is through the perspective of Wendt's constructivism [6].

If we refer to what Wendt perspective, ASEAN countries face some identity problems. Domestically, some countries still have to overcome the problems of social and political integrity. Indonesia and Philippines are the first countries that faced the problem of people's dissatisfaction to the authoritarian governments. The fall of the Marcos' and Soeharto's regimes shows the shifting identity of the role of individual actors. Myanmar became one of the international spotlights especially after the detention of Aung San Suu Kyi who fought for democracy and protection of human rights that had long been neglected by the military Junta. While in Thailand, the monarchy can no longer protect the regime of government from the mass movement. The similar thing happened in Malaysia, Anwar Ibrahim continue to mobilize the masses to encourage the acceleration of the reform movement.

In Indonesia under the Soeharto's regime, the interpretation of human rights must only be done by the regime. Stability became the main jargon in such a way that anything perceived as bothering national stability must be removed, including the critical voice of socially-inherited social implications that is supposedly always deliberately covered up. Some people started wondering about the meaning of independence that actually forms the basis of their citizens' identity, amidst corrupt practices, collusion, manipulation and nepotism that happened in every aspect of life. Besides economic and political issues, the tendency of cultural uniformity has grown the seeds of horizontal conflicts as a consequence of the silencing of the true differences in the identity of the nation. In addition to domestic problems, Indonesia and other Southeast Asia countries have also faced several regional problems. Indonesia hasn't agreed upon the extradition treaty with Singapore that hinders the completion of Indonesian corruption cases. Border conflicts among the countries in the region. Rohingya and Marawi are also contributing more complexity.

From this point of view, it seems that the formation of a common identity becomes impossible. Indeed, if we examine further, the various problems are born from various actions of actors who do not pay attention to others as equal parties. Southeast Asia during colonialism was a battleground between European countries. In World War II it became an Axis and Allied battleground. During the Cold War era, it was a battleground of war strategy with the hands of others (war by proxy) between the Western Bloc and the Eastern Bloc. Almost immediately after the declaration of independence, Southeast Asia is a battleground for economic giants like America, China and Japan. Southeast Asia has gone through various consequences of what the realists believe as anarchy. The rulers have simultaneously or alternately created overlapping geopolitical maps. The EU is currently facing a crisis, but with a shift in the view of collective identity, we can see that they can agree to jointly solve it, at least showing concern for openly seeking alternative solutions. ASEAN in some cases has not been able to show such behaviour; the internal conflicts of the region tend to involve a very disproportionate role from outside the region, especially the United States and China. 


\section{CONCLUSION}

It is time for ASEAN to fix the commitment not only in the rhetoric level. Regional cohesion will require the entire process of improving. The respect for every aspect of the lives of the actors, including human rights, is necessary precondition. Southeast Asia still has the hope of forming a strong collective identity by looking at this process through the formation of ASEAN countries community, and more importantly ASEAN people community. It is not going to be easy, but not impossible to achieve regional identity awareness.

\section{REFERENCES}

[1] J. S. Nye, International Regionalism: Readings. Little \& Brown Company, 1968.

[2] A. Hurrell, "Regionalism in theoretical perspectives," In Regionalism in World Politics: Regional Organization and World Politics. L. Fawcett, \& A. Hurrell, Oxford: Oxford University Press, 1995.

[3] A. Wendt, Social Theory of International Politics. Cambridge: Cambridge University Press, 1999.

[4] A. B. Phillips, "Constructivism", in International Theory for the Twenty-First Century: An Introduction, M. Griffiths, London: Routledge, 2007.

[5] L. Fawcett, "Regionalism in Historical Perspective," in Regionalism in World Politics: Regional Organization and World Politics. L. Fawcett, \& A. Hurrell, Oxford: Oxford University Press, 1995.

[6] S. Rother, "Wendt meets East: ASEAN cultures of conflict and cooperation," Cooperation and Conflict, vol. 47, No. 49, pp. 49-67, 2012. 